\title{
General Characterization of Cuticular Membrane Isolated from Agave salmiana
}

\author{
V. H. Perez-Espana ${ }^{1}$, J. A. Cuervo-Parra ${ }^{1}$, C. Paz-Camacho², M. A. Morales-Ovando 3 , C. A. Gomez-Aldapa ${ }^{4}$, \\ G. C. Rodriguez-Jimenes ${ }^{2}$, V. J. Robles-Olvera ${ }^{2}$, P. A. Lopez-Perez ${ }^{1}$ and T. Romero-Cortes ${ }^{{ }^{*}}$
}

${ }^{1}$ Escuela Superior de Apan, Universidad Autonoma del Estado de Hidalgo. Chimalpa Tlalayote (43 900), Mexico

2Unidad de Investigacion y Desarrollo en Alimentos. Instituto Tecnologico de Veracruz (91 897), Mexico

${ }^{3}$ Universidad de Ciencias y Artes de Chiapas, Acapetahua, Chiapas (30 580), Mexico

${ }^{4}$ Area Academica de Quimica, Instituto de Ciencias B asicas e Ingenieria, Ciudad del Conocimiento, Universidad Autonoma del Estado de Hidalgo (UAEH), Carretera Pachuca-Tulancingo Km. 4.5, C.P., Mineral de la Reforma, Hidalgo (42 183), Mexico

\section{Corresponding Author}

T. Romero-Cortes

e-mail: tromerocortes@gmail.com

\author{
Article History \\ Article ID: AR1950 \\ Received in $17^{\text {th }}$ January, 2019 \\ Received in revised form $13^{\text {th }}$ February, 2019 \\ Accepted in final form 19 $19^{\text {th }}$ February, 2019
}

\begin{abstract}
The plants of the genus Agave have a characteristic cuticular membrane that serves as an adaptation to arid conditions. The cuticular membrane of Agave salmiana is commonly used for the elaboration of certain regional culinary dishes in Mexico, due in part to its particular flavor. Unfortunately, when the cuticle is removed from the plant, it dehydrates very quickly and becomes brittle, which makes it necessary to extract more cuticles. In this work, our aim was to expand the knowledge on the composition of the $A$. salmiana cuticular membrane. Within the results it was found that the moisture content of the cuticular membrane of $A$. salmiana ranges between 50 and $60 \%$. Concerning Water activity $\left(a_{w}\right)$, there were no significant differences between diverse storage temperatures $\left(2,8\right.$ and $\left.22^{\circ} \mathrm{C}\right)$. On the other hand, considering the hue angle and luminosity, the obtained values were $80.25 \pm 1.29$ and $70.85 \pm 0.65$, respectively. Although, no significant changes were observed. The thickness of the cuticle of $A$. salmiana was $129 \pm 1.9 \mu \mathrm{m}$ and the fibers had a thickness of $30.7 \pm 3$ $\mu \mathrm{m}$. The heat flow thermograms correspond to those reported for the fatty acid transition ( 50 to $100^{\circ} \mathrm{C}$ ). This work contributes to the overall characterization of the A. salmiana cuticular membrane including the morphology, distribution and size of stomatal complexes and epidermal cells.
\end{abstract}

Keywords: Agave salmiana, cuticle membrane, DSC, humidity, stomatal complexes, water activity

\section{Introduction}

The outermost layer of maguey leaves, consists of a cuticle that interacts with the environment (Kunst and Samuels, 2003; Riederer and Muller, 2006). This is structural and generated by the evolution of the upper part of plants and works as an insulator and protector against the external surrounding environment (Shepherd and Wynne, 2006; Reina and Yephremov, 2009). Cuticle structure varies widely between plant species (Petit et al., 2007; Isaacson et al., 2009) and although apparently a minor component in terms of total leaf mass, its physical, chemical, mechanical and morphological properties, make it suitable for important roles. Its main functions are; a) reduction of water loss, as a solute and for diffusion of gases (Riederer and Schreiber, 2001); b) antiadhesive properties which influence plant-insect interaction and help prevent proliferation of pathogenic microbes (Reina and Yephremov, 2009); c) as an important thermoregulator for plant interactions with the environment, and provides protection against UV rays (Riederer and Muller, 2006); d) it provides mechanical support (Dominguez et al., 2009); e) it participates indirectly in correct organ formation during the first stages of plant development by preventing uncontrolled adhesion of epidermal cells (Riederer and Muller, 2006; Leide et al., 2011). The thick cuticle has often been reported to measure between 3 and $15 \mu \mathrm{m}$, mainly consisting of chitin and waxes (Gentry and Sauck, 1978; Park, 2003). Chitin is an insoluble biopolyester, which is cross-linked long chain hydroxylated fatty acids, whereas waxes are embedded in the polymer (intracuticular) or deposited on the exterior of the cuticle (epicuticular; Heredia et al., 1998).

Agaves have a characteristic cuticular membrane that serves as an adaptation to arid conditions. These membranes are thick and possess a waxy coating and complex stomas. Stomatal complexes (CE) interrupt the leaf surface which consists of occlusive cell pairs, the stomata and attached cells (Gentry and Sauck, 1978; Willmer and Fricker, 1996). Stomas enable gaseous exchange and act as a communicating aperture, as they are present on both front and back surfaces 
(Gentry and Sauck, 1978; Park, 2003). They play a vital role in maintaining plant homeostasis by controlling gas exchange and water loss (Nicanor et al., 2012). The $A$. salmiana species is considered to be the common ancestor of broad-leaved Agave species in Mexico (Heredia et al., 1998; Parra et al., 2010). In this country, the cuticular membrane of $A$. salmiana is used to make parchment paper (Parra et al., 2010) and for the elaboration of certain regional culinary dishes, owing to its particular flavor. Unfortunately, when the cuticle is removed from the plant, it dehydrates very quickly, becoming brittle. In order to avoid dehydration, traders moisten the cuticle and keep it in polyethylene bags. However this propitiates fungal growth, causing rapid decay. Although the cuticle of A. salmiana is greatly appreciated, we discovered no reports that providing enough information. In this work, our aim was thus to expand knowledge regarding composition of the $A$. salmiana cuticular membrane.

\section{Materials and Methods}

\subsection{Sampling}

Cuticle samples were obtained from the adaxial side of $A$. salmiana leaves, harvested in Hidalgo, Mexico. Samples were extracted using empirical techniques developed by the mixioteros (maguey workers). The technique consisted of making a horizontal cut in the apical area of the leaf, and slowly removing the membrane by pulling towards the base. Samples were selected according to the age of plants (8-10 years) and when they were cut. They were stored at 2, 8 and $22{ }^{\circ} \mathrm{C}$, as they were cut prior to analysis.

\subsection{Determination of moisture content and water activity}

We used the AOAC method (1995) to determine moisture content. Fresh samples of $1 \mathrm{~g}$ were placed in aluminum trays and incubated in a vacuum oven (Line Instrument brand) at $60^{\circ} \mathrm{C}$ and $45 \mathrm{kPa}$. Samples were taken every 5 days and weighed in an analytical balance (Ohaus) in order to maintain constant weight. Water activity $\left(a_{w}\right)$, was determined every 5 days for $1 \mathrm{~g}$ of pulverized sample, using the Dew-point method (Aqua Lab, Series 3). Experiments were undertaken in triplicate.

\subsection{Color evaluation}

We collected color samples every 5 days for evaluation. Values were determined for brightness, hue angle and chroma angle, using a colorimeter (MiniScan Hunter Lab's) and calculations were obtained with eqs. (1) and (2).

Chroma; $\mathrm{C}=\mathrm{Va}^{2}+\mathrm{b}^{2}$

Hue; $H=\sin ^{-1} \frac{b}{C}$

\subsection{SEM microstructure analysis}

Cuticles were dehydrated in a vacuum oven (Line Instrument brand) at $40^{\circ} \mathrm{C}$ and $45 \mathrm{kPa}$, then coated with a palladium-gold layer, fixed with carbon tape and observed under the scanning electron microscope JEOL JMS-5600LV.

\subsection{Stomatal index and stomatal density}

Stomatal index (SI) and stomatal density (SD) were determined using an optical microscope's 40X objective (Zeigen, ZB-7300). The SI was calculated using eq. (3) devised by Wilkinson (1979). SD was obtained by determining the number of stomata observed in an area of $4,347 \mathrm{~mm}^{2}$, equivalent to the diameter of the observed optical field.

stomatal index; $\mathrm{SI}=(\mathrm{EN} \times 100) /(\mathrm{EC}+\mathrm{EN})$

Where:

$\mathrm{EN}=$ Estomata number

$\mathrm{EC}=$ Typical epidermis cells

\subsection{Differential scanning calorimetry}

Lyophilized samples were cut into $5 \mathrm{~mm}^{2}$ sections with dissecting scissors, placed in $40 \mu \mathrm{L}$ aluminum crucibles and accurately weighed in a microbalance (Mettler Toledo model AX205). A Differential Scanning Calorimeter (DSC, Mettler Toledo model DSC822e) was used for the thermal analysis of the samples. Calibration of equipment was carried out with indium $\left(\Delta \mathrm{H}\right.$ fusion $=28.55 \mathrm{~J} \mathrm{~g}^{-1}$ and its melting point $=429.8$ $\mathrm{K})$. Temperature ranged from 0 to $400{ }^{\circ} \mathrm{C}$, heating at a rate of $10{ }^{\circ} \mathrm{C} \mathrm{min}{ }^{-1}$, with a continuous flow of $\mathrm{N}_{2}$ gas $\left(20 \mathrm{ml} \mathrm{min}^{-1}\right)$ that homogenized thermal conductivity inside the heating cell. The heating-cooling cycle consisted of an increase from room temperature to $200{ }^{\circ} \mathrm{C}$, remaining constant for $20 \mathrm{~min}$ and subsequently decreasing down to $25^{\circ} \mathrm{C}$. Tests were run in triplicate and results were analyzed using the equipment software.

\section{Results and Discussion}

\subsection{Moisture content and water activity $\left(a_{w}\right)$}

The moisture content of the cuticular membrane of $A$. salmiana was found to range between $50 \%$ and $60 \%$ (Figure $1 a)$. Concerning $a_{w}$, there was no significant difference
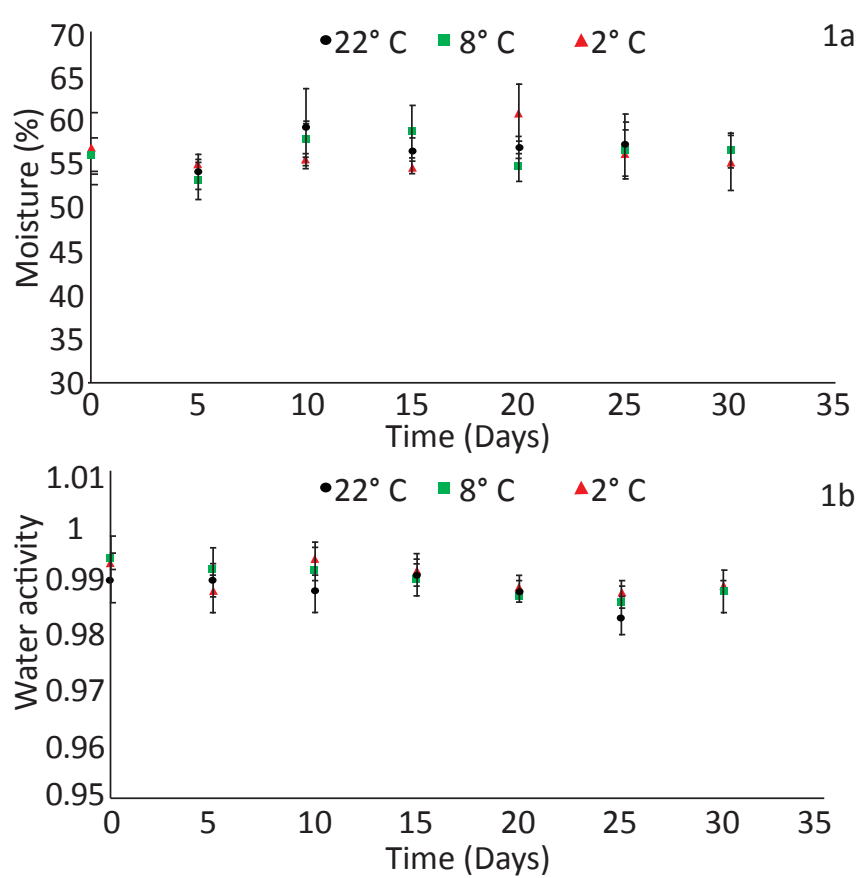

Figure 1: Moisture content and aw of the cuticle of $A$. salmiana at three temperatures 
between diverse storage temperatures $\left(2,8\right.$ and $22{ }^{\circ} \mathrm{C}$; Figure $1 \mathrm{~b})$, as values were generally $0.98 \pm 0.002$. Moisture is a factor that balances the temperature of plants and prevents them from drying out; whereas water activity $\left(a_{w}\right)$ is a property that helps to predict the stability and shelf-life of the cuticle. Environmental temperature and humidity in the storing chamber can be a strict control and it is known that cuticle properties are largely influenced by these two factors (Edelmann et al., 2005; Matas et al., 2005). Studies in cuticle mature tomatoes showed remarkable differences between dry and rehydrated samples. The last increased their extensibility and plasticity to minute temperature differences in the range from $7{ }^{\circ} \mathrm{C}$ to $30^{\circ} \mathrm{C}$. Water acts as a plasticizer for polymers, reducing their interactions and leading to an exponential decrease in energy inputs in areas where moisture is limited (Sanchez, 2003). The plasticizing effect of water on the cuticular membrane of plants from the Agave genus was observed for the first time by Petracek and Bukovac (1995), and subsequently confirmed in isolated cuticular membranes by several authors (Edelmann et al., 2005; Matas et al., 2005). This effect was also observed in cutin, which mainly consists of an insoluble biopolyester with a high degree of cross-linking between long chain hydroxylated fatty acids. Heredia et al. (1998); Lopez et al. (2007) and Dominguez et al. (2011) report that water molecules probably interact with cutin and polysaccharide fractions, decreasing the viscosity of these polymers and thus favoring the displacement of macromolecular polymer segments.

\subsection{Color}

Chroma values (color saturation) manifested significant variation, depending on storage temperature. Hue angle and luminosity, values were $80.25 \pm 1.29$ and $70.85 \pm 0.65$, respectively. Although no significant changes were observed, it is important to report these results, as there are few publications on this topic. Macroscopic change in color saturation was observed from day 35 and the presence of microorganisms (Figure 2). Storage temperature appeared to have a fungistatic effect, ensuring that cuticular membranes exhibited stability for more than 30 days. This time was longer than the 6 days reported by Parra et al. (2010).

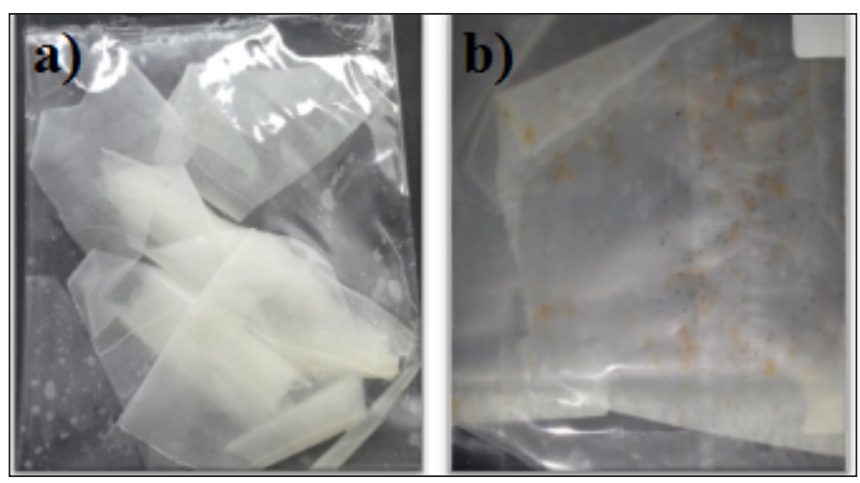

Figure 2: Evolution of color in the cuticle of A. salmiana as a function of time (a) 0 day and (b) 35 days

\subsection{Microstructural analysis}

The cuticle membrane of the adaxial side of $A$. salmiana presents values of $129 \pm 4.9 \mu \mathrm{m}$. The structure and components in the stomata complex (SC) and the presence of polygonal epidermal cells in the cuticular membrane of $A$. salmiana are depicted in (Figure $3 \mathrm{a}$ and $3 \mathrm{~b}$ ). The stomata complex appears to be tetracytic with a suprastomatal and substomatal chamber. No uniformity in its organization was observed and
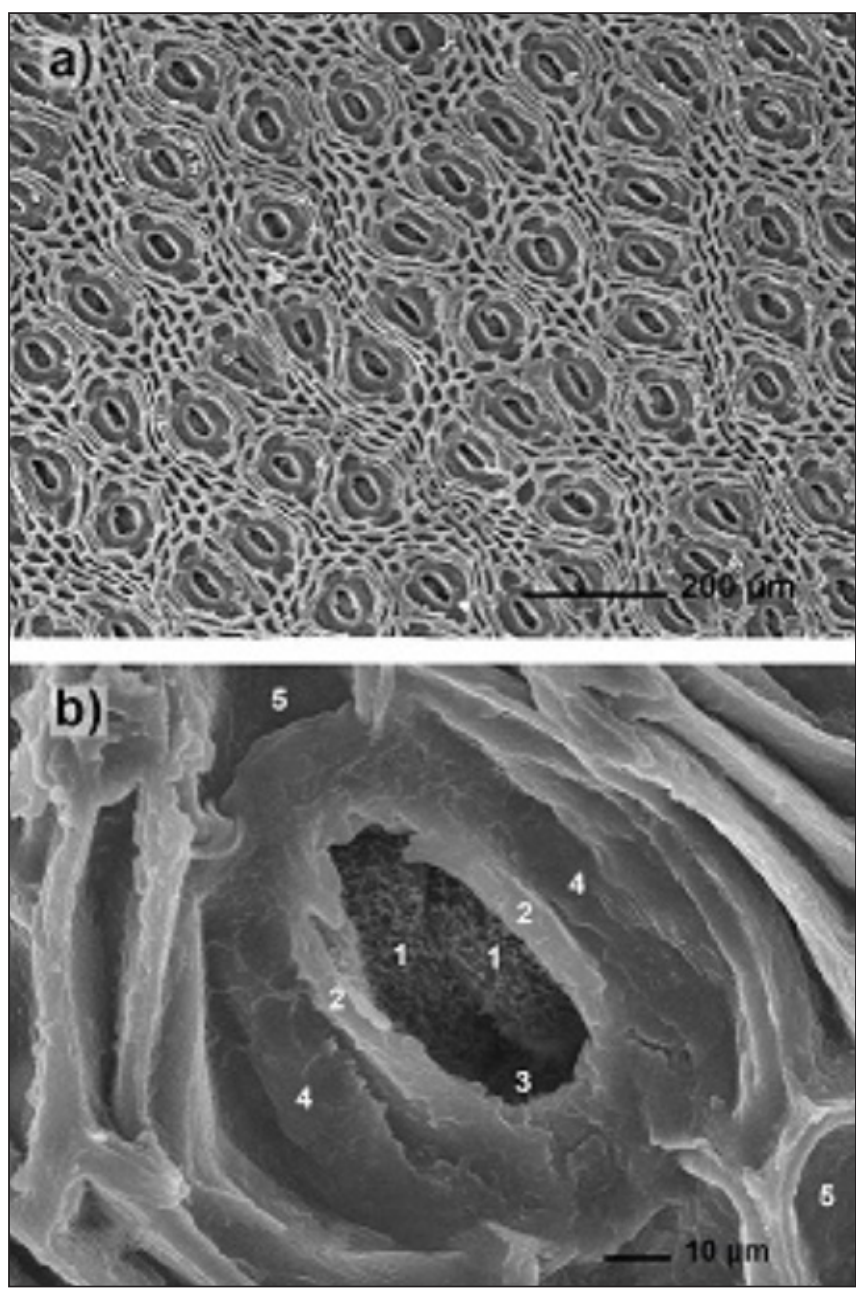

Figure 3: Micrograph of adaxial side from A. salmiana cuticle (A) and stomata complex (B). Cell guards (1), inner lateral subsidiary cells (2), terminal subsidiary cells (3), external lateral subsidiary cells (4) and normal epidermal cells (5)

it was $123.8 \pm 8.7 \mu \mathrm{m}$ long and $80 \pm 9.8 \mu \mathrm{m}$ wide.

Stomatal index (SI) and stomatal density (SD) may vary within the same leaf, depending on plant variety and ecological environment. SI and SD values were measured in each of three leaf zones. Values show the same distribution in the cuticle of A. salmiana (Table 1). Dimensions for the suprastomata cavity of the cuticular membrane are $46.6 \pm 4.2 \mu \mathrm{m}$ long by $27 \pm 2.64$ $\mu \mathrm{m}$ wide. The thickness of $A$. salmiana cuticle was $129 \pm 1.9 \mu \mathrm{m}$ and the fibers were $30.7 \pm 3 \mu \mathrm{m}$ thick (Figure 4), the presence of cutin and cuticular waxes is clearly visible. 


\begin{tabular}{lcc}
\hline \multicolumn{3}{l}{$\begin{array}{l}\text { Table 1: Stomata index (SI) and density }(\mathrm{mm} 2) \\
\text { cuticle }\end{array}$} \\
\begin{tabular}{lcc} 
Cuticle cut on sheet & SI & SD \\
\hline Apical & $0.99 \pm 0.001$ & $25.46 \pm 3.40$ \\
Middle part & $0.99 \pm 0.006$ & $28.86 \pm 0.06$ \\
Basal & $0.99 \pm 0.005$ & $31.69 \pm 9.30$ \\
\hline
\end{tabular}
\end{tabular}
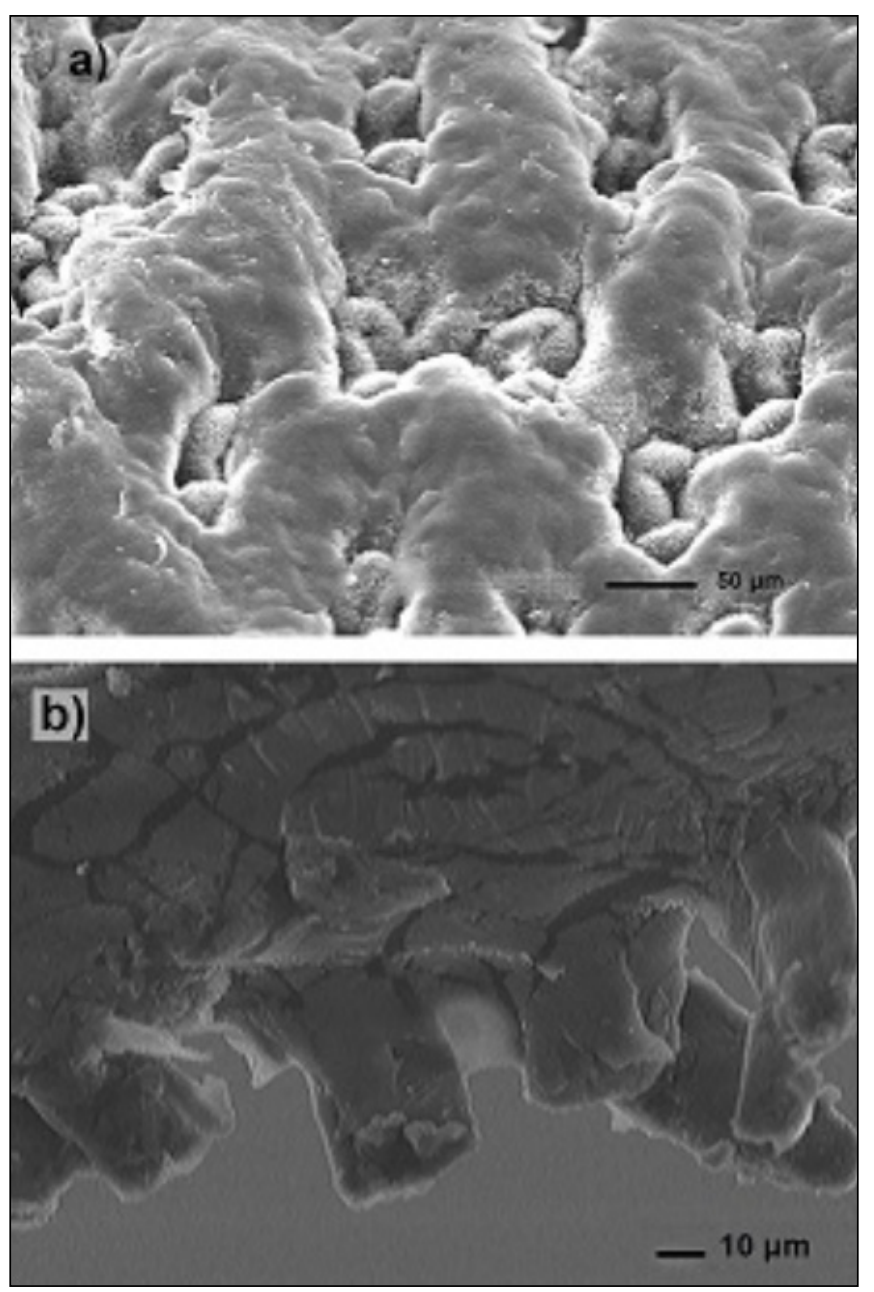

Figure 4: Fibers of the $A$. salmiana cuticle, embedded in cutina and cuticular waxes

The cuticle functions are not correlated with their thickness but with their structure, their chemical composition and the proportion of their components (Kerstiens, 2006; Yeats et al., 2012). However, in this work the importance of thickness lies in the use as a traditional dish wrapper. Several authors (Suarez et al., 2009; Franchini et al., 2010; Arevalo et al., 2011; Velazquez et al., 2014) have described the thickness of the cuticle membrane of fruits and leaves of plants which varies between $0.5 \mu \mathrm{m}$ and $1.5 \mu \mathrm{m}$, depending on plant species, area of plant, and its age or development stage (Stark and Tian, 2006; Tafolla et al., 2013). In a way similar to agaves, orchids have a cuticular thickness that enables them to control water storage enabling them to tolerate droughts (Arevalo et al., 2011). The same phenomenon has been observed in leaves of species such as Lycopersicon $(4.9 \mu \mathrm{m})$, Buxus (8.0 $\mu \mathrm{m})$, Galium (1.2 $\mu \mathrm{m})$, Ficus $(2.5 \mu \mathrm{m})$, Prunus $(4.7 \mu \mathrm{m})$, Pyrus $(2.6 \mu \mathrm{m})$, Vanilla $(3.3 \mu \mathrm{m})$, Helianthus annuus L. $(6.01 \mu \mathrm{m})$, Epidendrum excisum (12.7 $\mu \mathrm{m} \pm 1.68)$, Hirtzia escobarii (5.6 $\mu \mathrm{m} \pm 0.2)$, Rodriguezia lehmannii \pm 0.67$)$, Elleanthus oliganthus (4.6 $\mu \mathrm{m} \pm 0.8)$, Elleanthus purpureus (4.5 $\mu \mathrm{m} \pm 0.4)$, Pleurothallis cordifolia (7.9 $\mu \mathrm{m} \pm 0.7)$, Stelis sp. (4.6 $\mu \mathrm{m} \pm 0.4)$, several Oryza sativa L. (1.96-3.07 $\mu \mathrm{m})$ and Agave tequilana Weber (9 $\mu \mathrm{m})$.

Stomata complex from $A$. americana cuticular membrane is classified as type 1 , because it contains an external region or primary multilaminar cuticle, separated from a secondary cuticle (Jeffree, 1996). The stomata complex was identified, taking the ostiolo into account, as this is the space left by the guard cells (Arroyo, 2005). The structure of the SC of the $A$. salmiana showed similar characteristics to those reported for SC of $A$. atrovirens Karw (Bernardino et al., 2012). However, these were larger than the SC of Agave tequilana, measuring $17 \mu \mathrm{m}$ long and $39 \mu \mathrm{m}$ wide (Hernandez et al., 2003).

SI and SD are strongly related to environmental conditions such as droughts, which regulate transpiration and maintain plant turgor (Pares et al., 2004). The SD value recorded for $A$. salmiana is similar to the SD of several agave species reported previously; $A$. cerulata had an SD of $52, \mathrm{~A}$. nelsonii 37, $A$. derti $52, A$. sobria $34, A$. aurea $18, A$. capensis 31 and $A$. promontorii 21 (Gentry and Sauck, 1978). Bernadino et al. (2012) reported that SD in $A$. atrovirens varies according to plant age at 3, 6 and 9 years $(22,30$ and 29, respectively). However, the reported values for $A$. tequilana, SD and SI are 99.55 and 5.72, respectively. These values exceed those reported for several other agave species (Hernandez et al., 2003). This does not correspond to the SD of 30 to 50 stomas per $\mathrm{mm}^{2}$ observed in 80 species from the Agave genus, reported by Gentry and Sauck (1978).

Dimensions for the suprastomata cavity reported for $A$. tequilana are $6 \mu \mathrm{m}$ long by $7 \mu \mathrm{m}$ wide (Hernandez et al., 2003). Both supraestomatic cavity dimensions are greater in $A$. salmiana than those reported for $A$. tequilana: length by $87 \%$ and width by $74 \%$. Bernadino et al. (2012) reported that the size of the stomatal complex in $A$. atrovirens varies according to the age of the plant. At 6 years old, the suprastomata cavity of the plant is smaller in area $(53.84 \pm 6 \mu \mathrm{m})$ than at 3 and 9 years $(140.51 \pm 13 \mu \mathrm{m}, 70.77 \pm 7 \mu \mathrm{m})$, respectively. This difference was attributed to the distribution of cuticular wax (Bernadino et al., 2012).

\subsection{Differential scanning calorimetry}

The transition temperature of the lipids depends on the length of the chains and their degree of saturation. Figure 5 shows the heat flow thermograms of the cuticle, indicating a peak at an initial transitional temperature of $44.87^{\circ} \mathrm{C} \pm 11.53$ and a final temperature of $83.32{ }^{\circ} \mathrm{C} \pm 2.5$, with a maximum temperature at $96.85^{\circ} \mathrm{C} \pm 3.87$, so there is a wide temperature 


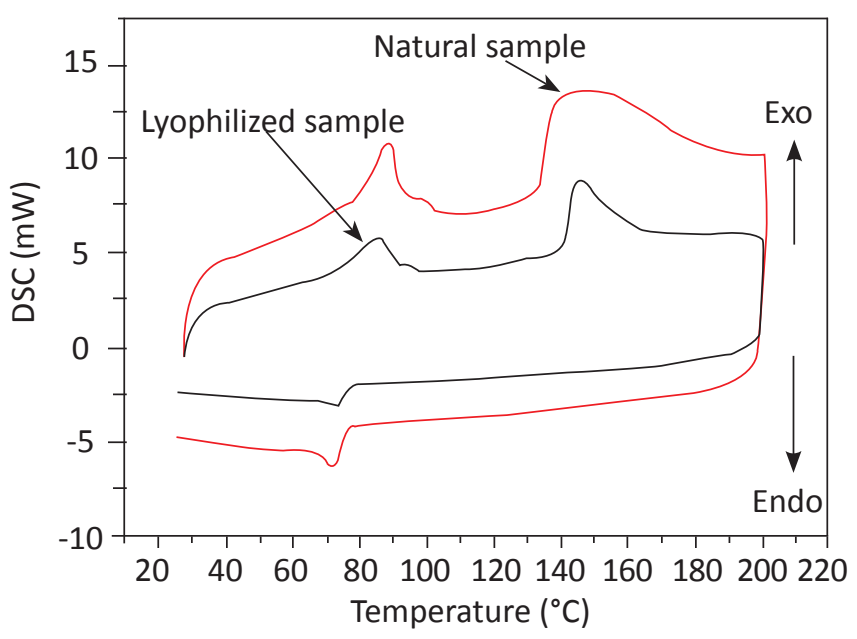

Figure 5: DSC curves of cuticles $A$. salmiana subjected to a heating-cooling cycle

range. This temperature corresponds to that reported for the transition of fatty acids $\left(50\right.$ to $\left.100^{\circ} \mathrm{C}\right)$. Exothermic peaks show a melting point of lipids and these are relatively wide, a fact which indicates wide dispersion in melting temperatures. This is due to the dispersion of the molecular weights of chemical compounds, present in the samples.

Due to the proximity of cutin matrix and cuticular waxes, it is difficult to distinguish one from another (ChungSuh et al., 2005). Heredia et al. (2013) report that cutin varies from 40 to $80 \%$ of the weight and according to the species and its thickness can vary from less than 1 to $10 \mu \mathrm{m}$ or more. Cutin is almost exclusively made up of 16-carbon fatty acids; 10,16-dihydroxyhexadecanoic acid and its 9,16-dihydroxyhexadecanoic positional isomer (Bessire et al., 2007) and by 18-carbon fatty acids; 9,10-epoxy-18-hydroxyoctadecanoic acid and 9, 10, 18-trihydroxyoctadecanoic acids (Heredia, 2003). The cuticle of the plants consists of waxy membranes with heterogeneous chemical composition, and each species manifests marked structural variability (Riederer and Schreiber, 2001). Cuticular wax accounts for $20-60 \%$ of the cuticle mass is a complex mixture of linear chain aliphatic compounds ranging from 20 to 40 carbons and wax esters with chains ranging from 36 to 70 carbons (Heredia, 2003). Arroyo (2005) carried out a comparative study of the foliar microstructures of three species of agaves (Agave tequilana, Agave americana and Agave angustifolia). On the adaxial side of bud leaves, it was evident that morphology of epicuticular waxes was similar in these three species, consisting of random thin and erect laminae, covering even the interior of the ostiolo of the stomatal complex (Arroyo, 2005).

Lipids, edible oils, and fats are abundant in many nutrition sources. Therefore, there are several reports about the use of DSC for the analysis of autoxidation and oxidative stability in food of high interest. The transitions observed in the thermogram correspond to first order changes that include water evaporation, as well as melting of lipids and other components (Martinez et al., 1998). This behavior is related to the lipid phase transition periods of the various compounds typically found in cuticles (Heredia et al., 1998). The second peak was observed to have more defined characteristics and higher energy expenditure, showing temperature ranges between $132.29^{\circ} \mathrm{C}$ and $167.4{ }^{\circ} \mathrm{C}$, and reaching its maximum energy consumption at a temperature of $160{ }^{\circ} \mathrm{C}$. During cooling, a lipids crystallization process was observed, initiating at a temperature between $63.4{ }^{\circ} \mathrm{C}$ with a maximum peak at $58.9^{\circ} \mathrm{C}$ and achieving crystallization at $78.6^{\circ} \mathrm{C}$. The presence of the second irreversible peak was attributed to water content.

There is limited information about the physical changes that the cuticle of the maguey undergoes after being extracted from the plant, such as becoming brittle to the touch. The heat flux curves obtained in the cooling process are consistent with those reported by Jimenez and Beltran (2003) in a study about application of DSC for the characterization of olive oil. This indicated thermograms with an exothermic peak, and a maximum temperature between $54.22^{\circ} \mathrm{C}$ and $39.52^{\circ} \mathrm{C}$. Fatty acid amide waxes (AAG) increase hardness and crystallization, at temperatures ranging between $40{ }^{\circ} \mathrm{C}$ and $60{ }^{\circ} \mathrm{C}$ (Gil et al., 2009).

\section{Conclusion}

This study describe the morphology, distribution and size of stomatal complexes, and epidermal cells of $A$. salmiana cuticular membrane. The cuticular membrane of $A$. salmiana was found to have greatest thickness that others cuticle of plants studied. Further studies will be necessary to define the composition of the waxes. It was observed that storage at low temperatures can conserve the color and flexibility of the cuticle for up to 66 days, thus extending its lifespan after removal from the plant.

\section{Acknowedgement}

The authors would like to thank Jessica Arlette Porcallo Rojas from ESAp-UAEH, for taking SEM micrographs.

\section{Conflict of Interests}

The authors of this research have no conflicts of interest to disclose.

\section{References}

Arevalo, R., Figueroa, J., Madrinan, S., 2011. Anatomia foliar de ocho especies de orquideas epifitas. Lankesteriana 11(1), 39-54.

Arroyo, J., Matias, F., Espinosa, S., Espinoza, H., Pena, A., 2008. Estudio comparativo de las microestructuras foliares en Agaves de importancia economica. Instituto de Fisiologia Celular, UNAM. INIFAP, Campo Experimental Valles Centrales, Oaxaca.

Bernardino-Nicanor, A., Mora, E.R., Soto, M.J., Santiago, 
F.K., Gonzalez, C.L., 2012. Microstructural differences in Agave atrovirens Karw leaves and pine by age effect. African Journal of Agricultural Research 7(24), 3550-3559.

Bessire, M., Chassot, C., Jacquat, A.C., Humphry, M., Borel, S., MacDonald-Comber, J., Pierre, J., Nawrath, C., 2007. A permeable cuticle in Arabidopsis leads to a strong resistance to Botrytis cinerea. The EMBO Journal 26(8), 2158-2168.

Boyer, J.S., 2015. Turgor and the transport of $\mathrm{CO}_{2}$ and water across the cuticle (epidermis) of leaves. Journal of Experimental Botany 66(9), 2625-2633.

Cazaurang-Martinez M., Herrera-Franco, P., Gonzalez, C.P., Aguilar, V.M., 1991. Physical and mechanical properties of Henequen fibers. Journal of Applied Polymer Science 43(4), 749-756.

Chung-Suh, M., Samuels, A.L., Jetter, R., Kunst, L., Pollard, M., Ohlrogge, J., Beisson, F., 2005. Cuticular lipid composition, surface structure, and gene expression in Arabidopsis stem epidermis. Plant Physiology 139(4), 1649-1665.

Dominguez, E., Espana, L., Lopez, C.G., Cuartero, J., Heredia, A., 2009. Biomechanics of isolated tomato (Solanum lycopersicum) fruit cuticles during ripening: the role of flavonoids. Functional Plant Biology 36(7), 613-620.

Dominguez, E., Heredia, G.J., Heredia, A., 2011. The biophysical design of plant cuticles: An overview. New Phytologist 189, 938-949.

Franchini, M.C., Hernandez, L.F., Lindstrom, L.I., 2010. Cuticle and cuticular wax development in the sunflower (Halianthus annuus L.) pericarp grown at the field under a moderate water deficit. International Journal of Experimental Botany 79, 153-161.

Gentry, H.S., Sauck, J.R., 1978. The stomatal complex in Agave: groups Deserticolae, Campaniflorae, Umbelliflorae. Proceedings of the California Academy of Sciences series 41, 371-387.

Heredia, A., 2003. Biophysical and biochemical characteristics of cutin, a plant barrier biopolymer. Biochimica et Biophysica Acta 1620(1-3), 1-7.

Heredia, A., Casado, C. G., Laguna, L., Reina, J.J., Serrano, J.M., Dominguez, E., 1998. La cuticula vegetal: Estructura y funciones. Ecologia 12, 293-305.

Hernandez, V.R.E.M., Lopez, F.R., Benavides, M.A., 2003. Micromorphology of the foliar epidermis of Agave tequilana WEBER. Agrofaz 3(2), 387-396.

Isaacson, T., Kosma, D.K., Matas, A.J., Buda, G.J., He, Y., Yu, B., Pravitasari, A., Batteas, J.D., Stark, R.E., Jenks, M.A., Rose, J.K., 2009. Cutin deficiency in the tomato fruit cuticle consistently affects resistance to microbial infection and biomechanical properties, but not transpirational water loss. The Plant Journal 60(2), 363-377.

Jeffree, C.E., 1996. Structure and ontogeny of plant cuticles. In: Kerstiens, G. (Ed.), Plant cuticle: an integrated functional approach. BIOS Scientific publishers, Oxford, 33-82.

Jetter, R., Kunst, L., Samuels, A.L., 2006. Composition of plant cuticular waxes annual plant reviews: In: Riederer, M., Muller, C. (Eds.), Biology of the plant cuticle. Oxford, UK: Blackwell Publishing, 145-181.

Jimenez, M.A., Beltran, M.G., 2003. Aplicacion de la calorimetria diferencial de barrido (CDB) en la caracterizacion del aceite de oliva virgen. Grasas y Aceites 54(4), 403-409.

Jimenez, M.A., Beltran, M.G., Aguilera, H.M.P., Uceda, O.M., 2007. Calorimetria diferencial de barrido. Influencia de la composicion del aceite de oliva virgen en su perfil termico. Grasas y aceites 58(2), 122-129.

Kerstiens, G., 2006. Water transport in plant cuticles: an update. Journal of Experimental Botany 57(11), 2493-2499.

Kunst, L., Samuels, A.L., 2003. Biosynthesis and secretion of plant cuticular wax. Progress In Lipid Research 42(1), 51-80.

Leide, J., Hildebrandt, U., Vogg, G., Riederer, M., 2011. The positional sterile (ps) mutation affects cuticular transpiration and wax biosynthesis of tomato fruits. Journal of Plant Physiology 168(9), 871-877.

Lopez, C.G., Matas, A.J., Dominguez, E., Cuartero, J., Heredia, A., 2007. Biomechanics of isolated tomato (Solanum lycopersicum L.) fruit cuticles: the role of the cutin matrix and polysaccharides. Journal of Experimental Botany 58(14), 3875-3883.

Matas, A.J., Cobb, E.D., Bartsch, J.A., Paolillo, D.J., Niklas, K.J., 2004. Biomechanics and anatomy of Lycopersicum esculentum fruit peels and enzyme-treated samples. American Journal of Botany 91(3), 352-360.

Pares-Martinez, J., Arizaleta, M., Sanabria, M.E., Brito L., 2004. Caracteristicas de las estomas, densidad e indice estomatico y su variacion en funcion a la enjertacion en Anona murica y Anona montana MADFAC. Bioagro 16(3), 213-218.

Park, S.N., 2003. Enviromental biology of agaves and cacti. Cambridge University Press, 284

Parra, N.L.A., del Villar, Q.P., Prieto, R.A., 2010. Extraccion de fibras de agave para elaborar papel y artesanias. Acta Universitaria 20(3), 77-83.

Petit, J.D., Gonzalez, L.A., Gonzalez, A.G., Sotelo, M.R., Baez, S.R., 2007. Cambios de la cuticula durante la ontogenia del fruto de Mangifera indica L. Revista Fitotecnia Mexicana 30(1), 50-60.

Petracek, P.D., Bukovac, M.J., 1995. Rheological properties of enzymatically isolated tomato fruit cuticle. Plant Physiology 109(2), 675-679.

Reina-Pinto, J.J., Yephremov, A., 2009. Surface lipids and plant defenses. Plant Physiology and Biochemistry 47(6), 540-549.

Riederer, M., Schreiber, L., 2001. Protecting against water loss: analysis of the barrier properties of plant cuticles. Journal of Experimental Botany 52(363), 2023-2032. 
Shepherd, T., Wynne, G.D., 2006. The effects of stress on plant cuticular waxes. New Phytologist 171(3), 469-499.

Suarez, J., Perez, C.M., Sanabria, C.M.E., Valera, R., Ulacio, D., 2009. Efecto de la temperatura y el estado de madurez sobre el grosor de la cuticula en frutos de guayaba (Psidium guajava L.). Revista UDO Agricola 9(1), 80-84. Tafolla, A.J., Gonzalez, L.A., Tiznado, H.M., Zacarias, G.L., Baez, S.R., 2013. Composicion, fisiologia y biosintesis de la cuticula en plantas. Revista Fitotecnia Mexicana 36(1), 3-12.
Wilkinson, H., 1979. The plant surface (Mainly leaf). In: Metcalfe, C.R., Chalk, Y. (Eds.), Anatomy of Dicotiledons. Oxford Claredous Press. London, UK, 97-165.

Yeats, T.H., Buda, G.J., Wang, Z., Chehanovsky, N., Moyle, L.C., Jetter, R., Schaffer, A.A., Rose, J.K.C., 2012. The fruit cuticles of wild tomato species exhibit architectural and chemical diversity, providing a new model for studying the evolution of cuticle function. The Plant Journal 69(4), 655-666. 